\title{
Research and Exploration of New Media Operation Courses
}

\author{
Xiaofang Liu \\ Sichuan Aerospace Vocational College \\ Chengdu, China
}

\begin{abstract}
As the society gradually develops, earthshaking changes have taken place in the way of communication in today's world. All kinds of We-Media have sprung up in our daily life. The society needs an increasing number of art design talents, so it is necessary for higher vocational colleges to constantly explore education and learning, bring forth new ideas, integrate digital media courses into new media, establish matched professional courses, train talents needed for social new media operation, and adapt to the development of the times. This paper introduces the problems new media operation faces, practical ways to improve the new media operation, and the influence of new media operation practice courses on the employment of vocational college students, and then the paper presents some constructive ideas from the aspects of curriculum reform and teaching method reform.
\end{abstract}

Keywords-new media; operation; teaching; higher vocational education

\section{INTRODUCTION}

In recent years, "We-Media" has been integrated into all walks of life, and the fusion of new and old media is a new trend that drives the development of the times. Sales have also shifted from original publicity marketing to online marketing and to fans attraction and traffic introduction. In the meantime, the original media ecological environment and employment environment of graduates in professional disciplines have undergone earth-shaking changes. A growing number of graduates enter to We-Media industry for entrepreneurship and employment. The society urgently needs to absorb a large number of talents for the development and operation of new media. As the main position for applied personnel training, higher vocational colleges must shoulder the burden of new media talent training. However, it cannot be denied that there exists some deflects in the curriculum and teaching of new media application in higher vocational colleges, which restricts the growth and expansion of new media operation talents.

\section{The Problems of Higher Vocational Colleges IN THE APPLICATION OF NEW MEDIA OPERATION}

\section{A. Too Single Application of New Media in Disciplines}

For the traditional media industry, paper advertising communication media is gradually declining compared with the rapid development of new media communication based on the Internet. For example, now the teaching method of digital media major in higher vocational colleges is single, which also belongs to traditional format design course, logo design courses and poster design courses. Students in higher vocational colleges still cannot adapt to the rapid development of social new media communication mode, so such courses cannot be applied in practice. As a result, students in higher vocational colleges encounter many problems in learning practical professional skills. Furthermore, there are more and more interdisciplinary and integrated subjects due to characteristics of "new media", and course teaching tends to be diversified. However, there are still some problems in new media operation teaching in colleges and universities in China, such as outdated curriculum content, weak professional practice and unreasonable professional curriculum arrangement. Individualized teaching is lacking, and it is difficult to train new media operation professionals what the society needs.

\section{B. Lack of Practical Teaching Experience in New Media Team}

Nowadays, the teaching mode of higher vocational colleges aims at cultivating students' professional skills in various aspects, but course teaching puts more emphasis on theoretical and the practice link is rigid. As a matter of fact, higher vocational college students are different from other students with higher degrees in absorption and learning ability, and many of their ideas cannot be translated into actual knowledge productive force. In addition, due to the short time of the emergence of new media, there are not enough classic cases compared with other fields. The lack of vivid cases in the classroom makes the course dull or even boring. Teachers seldom participate in enterprise marketing cases and can't renew the relevant information of "new media" in time. Students only have a preliminary understanding of "new media operation". Colleges lack market support. The resources of "college-enterprise cooperation" cannot meet the needs of colleges. Students want to do a good job in operation but lack the relevant data, and they cannot get user data analysis, and their specialized knowledge is just superficial. 
team building by means of microblog form and inspire students to actively think about problems and practice these them by themselves in the project operation and construct their knowledge, thinking and skills. In addition, the interactive teamwork with clear assignment distribution is required, because students can simulate the real market environment in the interaction, and experience the interest choices of other related parties, such as themselves, users and customers in the implementation of project. Rich and multi-level project roles and mutual collaboration create opportunities for students to quickly adapt to the work environment in the future.

\section{THE IMPACT OF NEW MEDIA OPERATION COURSES ON THE STUDENT EMPLOYMENT OF HIGHER VOCATIONAL COLLEGE} operation enterprises, and increase the opportunities for students to participate in research, analysis and training on large platforms. Colleges should also complete project tracking and research, add "training data case database", conduct regular return visit, and timely complete data collection, so as to improve database information.

\section{B. Changing Course Types}

According to the data of job category distribution of talent demand in new media operation market in 2016, the demand for talents who are capable of "text production and editing" is $33.9 \%$, talents of "video production and editing" is $0.4 \%$, talents of "data analysis" is $20.4 \%$, talents of "technical maintenance" is $1.3 \%$, talents of "customer service" is $16.1 \%$, and talents of "activity promotion" is $28 \%$. Data show that the highest demands in the current market are content production talents, accounting for up to $33 \%$.

Therefore, colleges need to change the traditional and backward teaching mode, build a new media operation teaching mode with market demand as the guide and students as the main body, improve the teaching efficiency of new media operation, and capture the key points in "new media operation courses". Colleges should expand general education courses, add courses on communication rules of social media, discover data analysis talents, train students' data modeling and analysis abilities, and offer courses of Modeling Art, Film and Television Art, Media Communication and Computer Technology (CG). These above courses belong to training practical course system, so colleges should add some related courses, such as video production, network program planning and new media content production.

\section{Increasing Course Team Project Construction}

Colleges should make use of "WeChat, microblog and client-side" to build a campus new media operation team, and create the campus "project teaching" mode. Colleges should rely on their own resources to build a college brand, regard the principle that educated people should meet the needs of modern society as the purpose, and train practical talents for the society. Colleges should carry out the teaching and learning of brand operation of the college through the interviewing and writing of "important campus news". In general, they should encourage students to participate in

\section{A. Joint Development by Three Parties}

Although the current employment situation is grim in China, there are several network platforms based on various forms, such as videos, words, photos and live broadcasts, which has opened a brand new employment channel for students. Relying on new media operation courses, colleges can provide more extensive personal platform for the majority of vocational students based on applied practice, and provide a new idea of "cooperation between school and enterprise". Besides, such method also can provide strong protection for employers who urgently need talent to fill the market.

\section{B. The Talent Demands of Small and Medium-sized Enterprises in Network and New Media Professionals}

As applied talent training colleges, they should pay attention to cultivating students' practical ability and basic professional quality. The application of new media is deeply rooted in our daily life, and part of the threshold of the Internet is also being lowered. Many students are more receptive and innovative than teachers in the reception and application of new media information. Therefore, under the guidance of the course, it is possible to incubate some excellent We-Media and small enterprises. The major of network and new media has strong application, is very cutting-edge and relies heavily on technology and data. However, there are some problems in its practice, so the future effects and changes need to be explored and thought by new media educators.

\section{CONCLUSION}

With the advent of the new media era, college students face new opportunities and challenges in their employment. Making good use of technical convenience brought by the new media era, catering to the market demand and adopting reasonable teaching methods of new media operation are the important tasks of training new media operation talents in higher vocational colleges. 


\section{REFERENCES}

[1] Zhao Jie. New Media Cross-Border Interaction Design, Beijing: Tsinghua University Press, New Media Cross-border Interaction Design, the first edition of October 2017. ISBN 978-7-302-47544-6. (in Chinese)

[2] Xie Shujun, Liang Genqin. On the Teaching of New Media Operation Course in Higher Vocational Colleges Under the Background of New Media. Blooming Season, 2018 (Early December Issue): 120-121. (in Chinese)

[3] Duan Zheng, Zheng Zhibin. Research on the Ideological Guidance of the New Media Operation Team in Colleges and Universities. Information Technology Exploration, 2018 (Early May Issue): 143144. (in Chinese)

[4] Peng Zhaoyi. Research and Exploration of Project-based Teaching of We-media Operation Course. Education Connection of Radio \& TV Journal, 2018 (10): 209-210. (in Chinese)

[5] Zhang Qinqin. On the Teaching of New Media Operation in Colleges and Universities Under the Background of New Media. Journal of News Research, 2017, 1674-8883 (2017)11-0270-01. (in Chinese)

[6] Zhang Meizhen. Research on Talent Demand and Cultivation of "New Media Operation" Talents for Network and New Media Majors in China, Journalism Education 2016 (12): 81-83. (in Chinese)

[7] Feng Qian. Employment Under the New Media Environment Based on the Operation of University Student Public Account. Media Form, 2018, 1 (11): 69-71. (in Chinese) 